\title{
NAUJAS POŽIŪRIS İ SKUBIOS MEDICINOS PAGALBOS KATEGORIJAS
}

\author{
Gintautas Virketis ${ }^{1}$, Veronika Matutytè ${ }^{2}$ \\ ${ }^{1}$ Klaipédos universitetinè ligonine, Klaipėdos universitetas, \\ ${ }^{2}$ Lietuvos sveikatos mokslu universitetas, Kauno klinikine ligonine, Geriatrijos klinika
}

Raktažodžiai: gyvybiškai būtina medicinos pagalba, skubios medicinos pagalbos kategorijos, priemimo ir skubios pagalbos skyrius.

\section{Santrauka}

Priemimo ir skubios pagalbos skyrius yra ta vieta, $i$ kurią pirmiausia greitoji medicinos pagalba ar patys pacientai kreipiasi dèl skubios medicinos pagalbos. Šiuose skyriuose yra gyvybiškai svarbus tinkamas paciento priskyrimas tam tikrai skubios medicinos pagalbos kategorijai. Šiuo metu naudojamos 4 skubios medicinos pagalbos kategorijos neatitinka praktiniu poreikių. Tyrimo rezultatai patvirtina, jog siekiant efektyvesnio prièmimo ir skubios pagalbos skyrių darbo, adekvataus pacientu pirminio sveikatos būklès vertinimo bei nuo to priklausančio tolimesnio ištyrimo ir gydymo, tikslinga pereiti nuo 4 iki 5 skubios medicinos pagalbos kategorijų naudojimo.

Atliktas kiekybinis tyrimas anketinès apklausos metodu, duomenų statistinè analizè, teorinis apibendrinimas. Respondentai - stacionarinių asmens sveikatos priežiūros ịstaigų ir greitosios medicinos pagalbos istaigu vadovai, reanimacijos ir intensyviosios terapijos bei prièmimo ir skubios pagalbos skyrių vedèjai. $71 \%$ respondentų mano, jog paciento kritinès būklès sąvoką atitinka tik 1 ir 2 skubios medicinos pagalbos (SMP) kategorijose ịvardintos klinikinès būklès. 68,1 proc. tyrime dalyvavusių respondentų pritaria ar visiškai pritaria, kad vietoj 4 būtų 5 SMP kategorijos. SMP kategorijoms apibūdinti respondentai iš 9 pavadinimų išskyrè šiuos: kritinès būklès, labai skubūs, skubūs, neskubūs, ambulatoriniai. 82,9 proc. respondentų pritaria nuomonei, kad GMP lape būtų žymimos SMP kategorijos.

Gyvybiškai būtina (gyvybei gelbèti ir išsaugoti) medicinos pagalba nèra tas pats, kas medicinos pagalba sveikatai gelbèti ir išsaugoti. 1 ir 2 SMP kategoriju klinikinès būklès galètų būti taikomos ,gyvybei gel- bėti ir išsaugoti“" sąvokos apibūdinimui. Šiuo metu naudojamos 4 skubios medicinos pagalbos kategorijos nepritaikytos ambulatorinès skubios medicinos pagalbos atvejams. Siūloma 5 SMP kategorijas su atitinkamais pavadinimais ir pagalbos teikimo laiko intervalais: kritinè būklè - nedelsiant (per $10 \mathrm{~min}$.), labai skubūs - 10-30 min., skubūs - nuo 30 min. iki 1 val., neskubūs - 1-2,5 val., ambulatoriniai - nuo 2,5 val. iki 4 val. Vienodas 5 SMP kategorijų taikymas GMP ir PSPS sumažintų transportuojamų pacientų srautus į PSPS.

\section{Ivadas}

Prièmimo ir skubios pagalbos skyrius (PSPS) yra ta vieta, i kurią pirmiausia greitoji medicinos pagalba (GMP) ar patys pacientai kreipiasi dèl skubios medicinos pagalbos (SMP). Lietuvoje stebima didejjanti pacientų srautų PSPS dinamika 2001-2014 metais [1], todèl reikalinga veiksminga sistema, leidžianti suteikti pacientams laiku ir kokybišką skubią medicinos pagalbą. İrodyta, kad pirminis paciento būklès vertinimas sumažina laukimo laiką iki SMP pagalbos teikimo pradžios: Australijoje 98\% prièmimo ir skubios pagalbos skyrių pacientų yra stacionarizuojami arba išleidžiami per 4 valandas nuo jų atvykimo [2]; Italijoje taip pat siūloma nacionaliniu mastu trumpinti pacientų buvimo PSPS laiką iki 4 valandų [3, 4]; Švedijoje, Danijoje, Olandijoje ịprastai pacientai pirmiausia kreipiasi į savo šeimos gydytojus, kurie gali patys suteikti reikiamą medicinos pagalbą, nes jie aptarnauja pacientus nuo 14 iki 24 valandų per parą arba nukreipti tiesiai ị ligonines aplenkiant priemimo ir skubios pagalbos skyrius [3, 5, 6]; Anglijoje nuo 2010 metų ịvesti nauji kriterijai po to, kai buvo nustatyta, jog pacientai priemimo ir skubios pagalbos skyriuje praleidžia iki 72 val. [7]. Pacientai, atvykę į PSPS, tikisi veiksmingos ir greitos pagalbos, todèl tikslas kuo greičiau atpažinti ir kuo tiksliau ịvertinti pacientų būklès sunkumą ir ūmumą ir šiam tikslui pasiekti pirminès medicininès apžiūros metu pacientas priskiriamas tam tikrai kategorijai. Pagal Lietuvoje galiojančius teisės 
aktus [8] visi ị prièmimo ir skubios pagalbos skyrių atvykę pacientai skirstomi pagal 4 skubios medicinos pagalbos kategorijas, kur 1 kategorijos pacientui medicinos pagalba turi būti pradèta teikti nedelsiant, 2 - ne vèliau kaip per $10 \mathrm{~min}$., 3 ir 4 kategorijos pacientai medicinos pagalbos turi sulaukti atitinkamai per 30 min. bei 1 val. Lyginant su užsienio mokslininkų pateikiamais duomenimis, kai siekiama skubią medicinos pagalbą suteiki ne ilgiau kaip per 4 valandas, Lietuvoje reglamentuotas SMP teikimo laikas iki 1 val. atrodo utopiškai gerai. Lietuvos pacientų koordinacinès tarybos narių apklausos duomenys, kuriuos kasmet pateikia UAB "Sveikatos vartotoju jëgaine’" (angl. Health Consumer Powerhause) organizacija, nurodo realesni SMP laukimo laiką: 2013 m. pacientai nurodè, kad laukè mažiau nei 1 val., 2014 m. nurodytas laukimo laikas 2,5 val. [9]. Deja, bet detalesniu mokslinių darbų, nagrinėjančių pacientų patirtị priėmimo ir skubios pagalbos skyriuose Lietuvoje nèra atlikta, todèl kiek pacientai užtrunka Lietuvos gydymo įstaigų prièmimo skubios pagalbos skyriuose laukdami, kol bus apžiūrèti ir suteikta skubi medicinos pagalba, nėra žinoma. Užsienio mokslininkai nurodo, jog i PSPS kreipiasi skirtingo amžiaus grupių pacientai dèl ūmių sveikatos sutrikimų, lètinių ligų paūmèjimo ir kitais atvejais, vedami ịsitikinimo, jog gaus kokybiškesnę ir greitesnę paslaugą, nei kreipiantis į šeimos gydytoją [10]. Tai gerokai pailgina pacientų apsilankymo priemimo ir skubios pagalbos skyriuose laiką. Šiuo metu Lietuvoje taikomas pacientų būklès vertinimas pagal 4 SMP kategorijos nepalankus medikams ir pacientams dar ir dèl to, kad skubios medicinos pagalbos masto lentelèje ịvardintos būklès labiau atitinka tokias būkles, dẻl kurių pacientą reikia stacionarizuoti, ir labai menkai apima pacientus, kuriems indikuotina ambulatorine skubi medicinos pagalba. Aukščiau minèta 4 kategorijų skalè netinkama ir pediatrinio profilio ligoniams, todèl kai kuriose ligoninèse naudojamos modifikuotos ir įstaigų vadovų patvirtintos pagalbos pirmumo vaikams vertinimo skalès [11].

Vystantis prièmimo skubios pagalbos skyriams ir centrams daugelyje progresyvių šaliu pradètos taikyti tokios pagalbos pirmumo nustatymo skalès, kaip: ATS (Australian triage system), MTS (Manchester triage system), CTAS (Canadian triage assessment system), ESI (Emergency severity index) ir METTS (medical emergency triage and treatment system). Remiantis Christ (2010), Van Veen (2009) atliktais tyrimais ESI ir MTS sistemos yra patikimos vaikams, CTA patikimumas yra vidutinis, o ATS sistema yra mažiausiai patikima vertinant vaikų būklę. Visos aukščiau išvardytos skalès yra sudarytos iš 5 kategorijų, o tarptautinè patirtis rodo, kad būtent tokios skalès yra labiausiai pritaikomos ir populiariausios priskiriant stacionarizuojamus ir ambulatoriškai gaunančius skubią medicinos pagalbą pacientus bei vaikus tam tikrai kategorijai bei suteikiant jiems reikalingą ir savalaikišką skubią medicinos pagalbą [12].

Darbo tikslas: ištirti ir įvertinti skubią medicinos pagalbą organizuojančių ir teikiančių specialistų požiūrị ị šiuo metu naudojamų 4 kategorijų skubios medicinos pagalbos skalès taikymo trūkumus bei siūlomą 5 kategorijų skubios medicinos pagalbos skalę.

\section{Darbo medžiaga ir metodai}

Atliktas kiekybinis tyrimas anketinès apklausos metodu, duomenų statistinė analizè, teorinis apibendrinimas. Respondentais pasirinkti stacionarinių asmens sveikatos priežiūros istaigų ir greitosios medicinos pagalbos ịstaigų vadovai, reanimacijos ir intensyviosios terapijos bei priemimo ir skubios pagalbos skyrių vedejai. Anketos sudarytos vieno iš autorių ${ }^{1}$.

Anketų duomenų analizei naudota SPSS 21 programa. Statistinèje analizejje ryšiai tarp požymių vertinti chi kvadrato $(\chi 2)$ kriterijumi, 95 proc. pasikliautinų intervalų, vidurkių lyginimo statistiniais metodais. Statistiškai reikšmingam rezultatų skirtumui ịvertinti pasirinktas $\mathrm{p}<0,05$, statistiškai labai reikšmingam $-\mathrm{p}<0,01$ lygmuo. Atsakymų variantai Nr.6, atitinkantys reikšmę ,nežinau“, interpretuoti kaip „,neatsakyta" i klausimą, siekiant apskaičiuoti vertinimų vidurkius balais 5 balų sistemose, kur balas 1 atitinka priešingą reikšmę balui 5 .

\section{Rezultatai ir jų aptarimas}

Paciento būklés ịvertinimo, kaip proceso, rezultatas yra gerai suplanuotos skubios medicinos pagalbos teikimas pacientui, siekiant stabilizuoti ir palaikyti jo gyvybines funkcijas bei numatant tolimesnę veiksmų seką [13]. Pagrindinis pagalbos pirmumo nustatymo skalių tikslas yra rūšiuoti atvykstančius pacientus, pirmiausia atrenkant tuos, kurie negali ilgai laukti [14]. Nustatyta, kad kuo greičiau pradètas gydymas trauminiams pacientams, tuo geresni gydymo rezultatai, mažesnis neiggalumo laikotarpis, trumpesni lovadieniai [15]. Galima teigti, kad pirminiam pacientų būklès vertinimui reikia teikti ypatingą dèmesị pasirenkant vertinimo priemones ir atitinkamai parengiant tam medicinos personalą.

LR Sveikatos sistemos įstatyme [16] nurodyta, kad GMP paslaugos bei reanimacijos ir intensyvios terapijos skyriuose teikiamos paslaugos priskiriamos paslaugoms, skirtoms gyvybei gelbèti ir išsaugoti. Gyvybiškai būtina (gyvybei gelbèti ir išsaugoti) medicinos pagalba nèra tas pats, kas medicinos pagalba sveikatai gelbèti ir išsaugoti [17]. Tačiau nèra poịstatyminių aktų, nurodančių ir išskiriančių medicinines indikacijas, kurias būtu galima priskirti gyvybei gelbèti ir išsaugoti paslaugų kategorijai. Siekta sužinoti respondentų nuomonę, ar visos SMP kategorijos, ar tik kai kurios iš jų gali būti traktuojamos kaip gyvybiškai būtina medicinos 
pagalba. Atsakymų raiška pateikta 1 paveiksle.

$71 \%$ respondentu mano, jog tik 1 ir 2 SMP kategorijos klinikinès būklès galètų atitikti paciento kritinès būklès sąvoką. Rezultatai nesiskiria statistiškai reikšmingai, atsižvelgiant ị respondentų amžių, lytị, stažą, ASPI steigèją ir ASPI lygmeni ( $\chi^{2}$ kriterijus, $p>0,05$ ). Toks rezultatas paaiškina gyvybiškai būtinos medicinos pagalbos sampratos svarbą ir iš dalies apibrèžtų šiai sampratai priskirtinas medicinines indikacijas. Šiuo metu įstatymu ar kitu teisès aktu šią sampratą atitinkančios medicininès indikacijos dar nėra ịvardytos. Todèl remiantis tyrimo rezultatais esamas SMP būklių skirstymas gali pasitarnauti tokių indikacijų sudarymui.

Siekiant nustatyti nuomonę apie specialistų požiūrị ị kategorijų praplètimą, respondentų buvo klausiama, ar jie pritaria, kad pacientai pagal laiką, per kurị turi būti pradèta teikti SMP, būtu išskirti ne ị keturias, kaip yra šiuo metu, bet 5 kategorijas. Atsakymų raiška pateikiama 2 paveiksle.

68,1 proc. tyrime dalyvavusių respondentų pritaria ar visiškai pritaria, kad laikas, per kurị turi būti pradèta teikti SMP, būtų išskiriamas ị 5 kategorijas (atitinkamai 55,2 proc. ir 12,9 proc.). Beveik penktadalis (18,1 proc.) neturi nuomonès, ir tik mažesnè dalis, kiek daugiau nei dešimtadalis, (13,8 proc.) visiškai nepritaria. Rezultatai nesiskiria statistiškai reikšmingai atsižvelgiant ị respondentų lytị, stažą, ASPI steigèją, ASPİ specialistų tipą ir ASPİ lygmenị, tačiau skiriasi statistiškai reikšmingai $\left(\chi^{2}\right.$ kriterijus, $\left.p<0,05\right)$ atsižvelgiant ị respondentų amžių. Rezultatų sklaida pateikiama 3 pav.

Nuomonei, kad pacientai pagal skubios medicinos pagalbos teikimo laiko pradžią būtų išskirti i 5 kategorijas dažniau „visiškai pritaria“ 60 ir daugiau metų turintys specialistai.

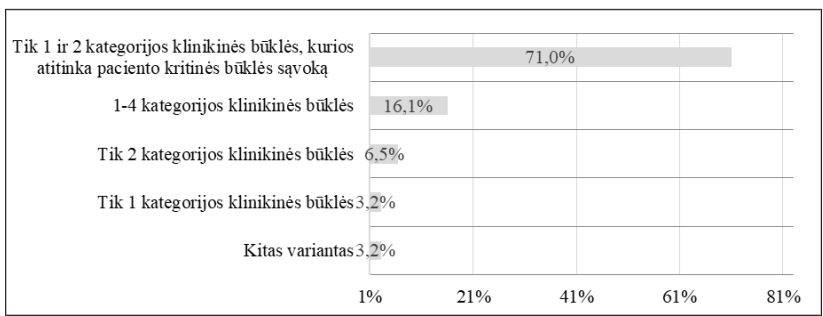

1 pav. SMP kategorijų atitiktis apibūdinant, ,gyvybiškai būtinos medicinos pagalbos"s sampratą, proc.

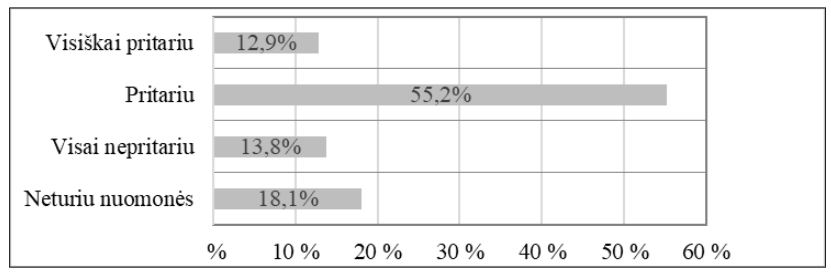

2 pav. Nuomonių dèl SMP kategorijų praplètimo pasiskirstymas, proc. ${ }^{1}$
Respondentams pritarus dèl SMP kategorijų praplètimo nuo 4 iki 5, norint aiškiai atskirti kategorijas buvo pasiūlyta išsirinkti labiausiai respondentų manymu tinkančius kategorijų pavadinimus. 4 paveiksle nurodyti dažniausiai respondentų pasirinkti pacientų sveikatos būklès vertinimo kategorijų pavadinimai.

Kaip matyti iš pateikto paveikslo, respondentai daugiausia pasirinko šiuos pavadinimus SMP kategorijoms apibūdinti: kritinès būklès, skubūs, ambulatoriniai, neatidèliotini, neskubūs. Šie pavadinimai iš esmès apima visas būkles nuo kritiškos iki ambulatorinès. Išdèsčius jas pagal loginị būklès sunkumo suvokimą, eiga atrodo taip (nuo sunkiausios iki lengviausios): kritinès būklès, neatidèliotini, skubūs, neskubūs, ambulatoriniai. Vietoj pavadinimo ,neatidèliotini“ (terminas angl. immediate) autoriaus ${ }^{1}$ siūloma vartoti praktiškesnị pavadinimą - „labai skubūs“. Grafoje „kita“ respondentų pateikti tokie rečiau vartojami terminai: „ne PSPS pacientai“, „lètinių ligų paūmèjimai“, „planiniai-lètiniai““.

Kita klausimo dalis susijusi su apžiūros laiko paskyrimu pasirinktų kategorijų pavadinimams.

Respondentų pasirinktų kategorijų sąsajos su laiku pateiktos 1 lentelèje.

Respondentai pateikè ir kitų kategorijų ir laiko derinių pasiūlymų, kurie netilpo ị anketoje sugrupuotus intervalus, bet $i$ juos buvo atsižvelgta dèl praktiškumo paslaugos teikimo laiko prasme: ,,ambulatoriniai daugiau 4-6 val.““; ,ambulato-

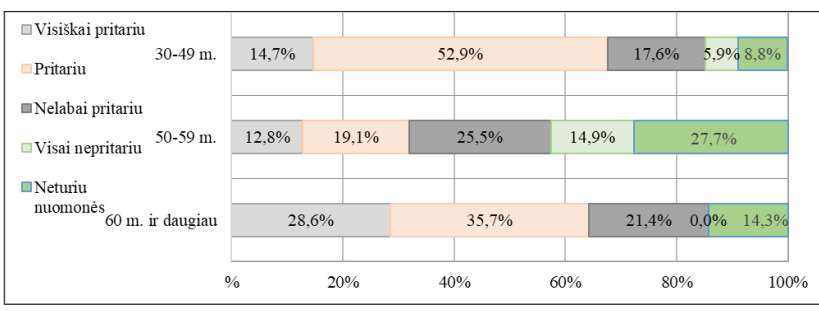

3 pav. Nuomonių dèl SMP kategorijų praplètimo pagal respondentų amžiu pasiskirstymas, proc.

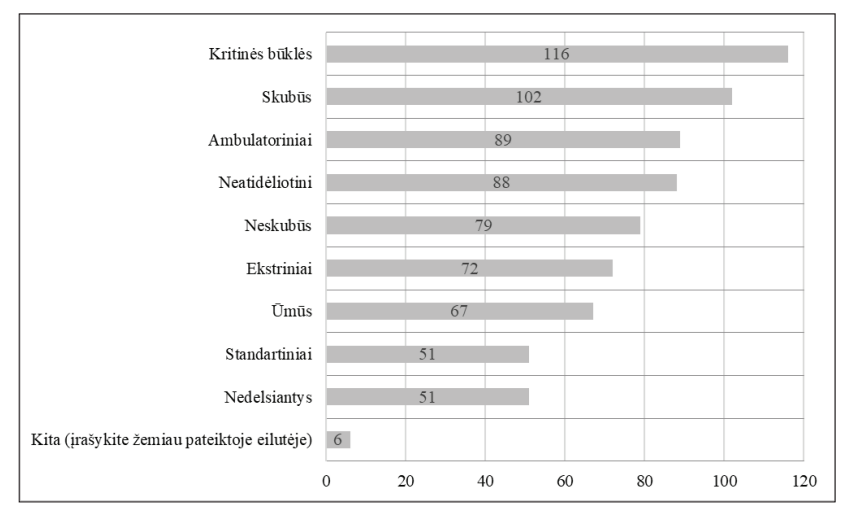

4 pav. Kategorijų pavadinimų pasirinkimo dažniai pagal atvejų skaičių, vnt. 


\section{4}

riniai ir standartiniai 6 ir daugiau val.“; ,,standartiniai iki 3-4 val.“; „neskubūs iki 5 val.“ ir kt. Tokiu būdu, naudojant 5 kategorijų skalę, sprendžiama problema, atskiriant pacientus, kuriems indikuotina ambulatorine skubi medicinos pagalba ir stacionarizuojamus tolimesniam ištyrimui ir gydymui pacientus bei nustatant konkrečius laiko intervalus, per kuriuos turètų būti pradèta taikyti skubi medicinos pagalba.

Pacientų apsilankymo prièmimo ir skubios pagalbos skyriuose bei reikalingos skubios medicinos pagalbos suteikimo laikas sumažètų, jei greitosios medicinos pagalbos darbuotojai naudotų standartizuotą universalią (pritaikoma kaip GMP taip ir PSPS) pirminę paciento sveikatos būklès vertinimo skalę ir tokiu būdu atvežtas ị PSPS pacientas jau būtų priskirtas konkrečiai kategorijai. Pastaruoju metu skiriamas dèmesys naujoms studijoms, ieškančioms būdų ir priemonių, kurios pagerintų pacientų sveikatos būklès įvertinimą, pacientų prioretizavimo kokybę, padètų valdyti visų rūšių išteklius. Nustatyta [18], kad Lietuvoje GMP darbuotojai neturi ar nenaudoja lengvai pritaikomų, irodymais paremtų ir patikimų pagalbos pirmumo nustatymo instrumentu, padedančių suklasifikuoti pacientus pagal būklès sunkumą dar ikistacionariniu periodu ir tinkamai perduoti informaciją PSPS darbuotojams. Greitosios medicinos pagalbos darbuotojai taip pat nevertina medicinos pagalbos teikimo skubumo pagal 4 skubios medicinos pagalbos kategorijas, tik palydimajame rašte nurodo GMP iškvietimo kategoriją, dèl ko iškyla motyvuotų prièmimo ir skubios pagalbos skyrių darbuotojų priekaištų, kad pacientai vežami nevertinant būklès, dažnai pagal pacientų pageidavimus [19].

Todèl buvo siekiama sužinoti respondentų nuomonę apie vienodų SMP kategorijų žymèjimo GMP lape tikslingumą. 82,9 proc. respondentu pritaria nuomonei, kad GMP lape būtų žymimos SMP kategorijos. Tik kiek daugiau nei dešimtadalis (12,2 proc.) respondentų tokiam žymèjimui nepritaria. Labai maža dalis respondentų neturi nuomonès (4,9 proc.). Pritarimas SMP kategorijos žymejjimui GMP lape nesiskiria statistiškai reikšmingai atsižvelgiant ị visus sociodemografinius respondentų parametrus. Analizuojant atsakymus pagal

1 lentelè. Skirstinys pagal laiką, per kurị pacientams turètų būti pradèta teikti SMP

\begin{tabular}{|c|c|c|c|c|c|}
\hline \multirow[t]{2}{*}{ Kategorija } & \multicolumn{5}{|c|}{$\begin{array}{c}\text { Laikas, per kurị šių kategorijų pacientams turètų būti pradėta } \\
\text { teikti pagalba (proc.) }\end{array}$} \\
\hline & $\begin{array}{c}\text { Nedelsiant } \\
\text { (per } 10 \text { min.) }\end{array}$ & $\begin{array}{c}\text { Nuo 10 } \\
\text { min. iki } 30 \\
\text { min. }\end{array}$ & $\begin{array}{l}\text { Nuo } 30 \text { min. } \\
\text { iki } 1 \text { val. }\end{array}$ & $\begin{array}{l}\text { Nuo } 1 \text { val. } \\
\text { iki } 2 \text { val. } \\
30 \text { min. }\end{array}$ & \begin{tabular}{|c} 
Nuo 2 val. \\
30 min. \\
iki 4 val.
\end{tabular} \\
\hline Kritinès būklès & 94,8 proc. & & & & \\
\hline Labai skubūs & & 68,4 proc. & & & \\
\hline Skubūs & & & 66,6 proc. & & \\
\hline Neskubūs & & & & 68 proc. & \\
\hline Ambulatoriniai & & & & & 62,9 proc. \\
\hline
\end{tabular}

respondentų tipus, tik apie penktadalis (24,1 proc.) GMP ìstaigų vadovų nepritaria skubios medicinos pagalbos kategorijos žymejjimui greitosios medicinos pagalbos lape. Kitu tipų respondentai nepritaria žymiai rečiau.

Pagal šiuo metu galiojančius teisès aktus SMP kategorijos neatitinka greitosios medicinos pagalbos iškvietimo tipo ir reagavimo kategorijų [20]. Todèl greitoji medicinos pagalba gali atvežti pacientą, kuriam pagal SMP kategorijas nereikia teikti pagalbos, o pagal GMP iškvietimo tipo ir reagavimo kategorijas atitinkamas iškvietimas turi būti vykdomas per 30 min. 94,7 proc. GMP atstovų patvirtino, kad GMP veža pacientus ị gydymo ịstaigas, reikalaujant pacientams ar jų artimiesiems net ir nesant būtinosios medicinos pagalbos poreikio.

Ivertinus atsakymų duomenis galima teigti, kad SMP kategorijų žymėjimas GMP palydimajame lape būtų vienas iš žingsnių bendro paciento būklès vertinimo protokolo link ir leistų PSPS gydytojui greičiau ir teisingiau apsispręsti del pagalbos teikimo eiliškumo. Kadangi dažnai GMP ir PSPS darbuotojai skirtingai vertina paciento būklès sunkumą, bendri ar tęstiniai protokolai padètų išvengti šių problemų. Tikètina, kad tai pagerintų skubios medicinos pagalbos paslaugų prieinamumą ir savalaikiškumą PSPS.

\section{Išvados}

1. Gyvybiškai būtina (gyvybei gelbeti ir išsaugoti) medicinos pagalba nèra tas pats, kas medicinos pagalba sveikatai gelbėti ir išsaugoti. Nesant patvirtintų medicininių indikacijų, kurias būtų galima priskirti gyvybei gelbèti ir išsaugoti paslaugų kategorijai, 1 ir 2 SMP kategorijų klinikinès būklès galètų būti taikomos ,gyvybei gelbeti ir išsaugoti“ sąvokos apibūdinimui.

2. Šiuo metu naudojamos 4 skubios medicinos pagalbos kategorijos iš esmès pritaikytos stacionarizuojamiems pacientams ir neapima ambulatorinès skubios medicinos pagalbos atvejų.

3. Siūloma naudoti 5 SMP kategorijas, koreguoti SMP kategoriju pavadinimus ir laiko intervalus, per kuriuos turètų būti pradèta teikti skubi medicinos pagalba: kritinè būklè - nedelsiant (per 10 min.), labai skubūs - 10-30 min., skubūs - nuo 30 min. iki 1 val., neskubūs - 1-2,5 val. bei ambulatoriniai - nuo 2,5 val. iki 4 val.

4. GMP tarnybai vertinant paciento būklę pagal tas pačias 5 SMP kategorijas, kurios būtų taikomos paciento būklei vertinti atvykus pacientui i PSPS, dalies pacientų transportuoti į ligonines nebūtų poreikio. Pacientams, kurių būklè 
atitinka 4-5 SMP kategoriją, pagalba galètų būti suteikiama vietoje arba rekomenduojama kreiptis ị savo šeimos gydytoją.

\section{Literatūra}

1. Lietuvos sveikatos informacijos centras, HI SIC, 2015.

2. Jones P, Schimanski K. The four-hour target to reduce emergency department "waiting time": A systematic review of clinical outcomes. Emergency Medicine Australasia, 2010; 22: 391-8. https://doi.org/10.1111/j.1742-6723.2010.01330.x

3. Pines JM. et al. International perspectives on emergency department crowding. Acad Emerg Med 2011; 18(12):1358-70. https://doi.org/10.1111/j.1553-2712.2011.01235.x

4. Vedovotto A. et al. Te burden of inappropriate emergency department pediatric visits: why Italy needs as urgent reform. Health Serv Res 2014; 49(4):1290-305. https://doi.org/10.1111/1475-6773.12161

5. Van Veen M. et al. Referral of nonurgent children from the emergency department to general practice: compliance and cost saving. Eur J Emerg Med 2012; 19(1):14-9.

https://doi.org/10.1097/MEJ.0b013e32834727d4

6. Grol R, Giesen P, Van Uden C. After-hours are in the United Kingdom, Denmark and the Netherlands: new models. Health Aff (Millwood), 2006; 25(6):1733-7. https://doi.org/10.1377/hlthaff.25.6.1733

7. Heyworth J. Emergency Medicine - Quality Indicators: The United Kingdom Perspective. Academic Emergency Medicine 2011; 18(12):1239-41.

https://doi.org/10.1111/j.1553-2712.2011.01223.x

8. Lietuvos Respublikos sveikatos apsaugos ministro isakymas Nr. V-1004 "Dèl greitosios medicinos pagalbos iškvietimų ịvertinimo ir greitosios medicinos pagalbos brigados siuntimo ị iškvietimo vietą tvarkos aprašo patvirtinimo", 2015-09-27, Vilnius (Valstybės žinios; Nr.160-5860).

9. Gurevičius R. Kuriant ị pacientą orientuotą sveikatos priežiūros sistemą. Higienos institutas. Visuomenès sveikata, 2015; 1(68):5-8.

10. Wai CKA, Chor MC, Lee CTA, Sittambunka Y. et al. Analysis of trends in emergency department attendances, hospital admissions and medical staffing in a Hong Kong university hospital: 5-year study. International Journal of Emergency Medicine 2009; 2:141-8. https://doi.org/10.1007/s12245-009-0098-7

11. Burokienè S. Ikihospitalinė vaikų priežiūra prièmimo ir skubios pagalbos skyriuose ir jos optimizavimo kryptys. Daktaro disertacija, Vilnius, 2015.

12. Lidal BI, Hilde HH, Gunn EV. Triage systems for pre-hospital emergency medical services a systematic review. Scandinavian Journal of Trauma, Resuscitation and Emergency Medicine 2013; 21(28):21-8.

https://doi.org/10.1186/1757-7241-21-28
13. Virketis G., Stašys R., Butrimas V. Patient flow management in emergency medicine using triage scales. Health sciences 2016; 26(4): 93-100.

14. Gilboy N, Tanabe P, Travers D, Rosenau MA. Emergency Severity Index (ESI): a triage tool for Emergency Department Care. Version 4, 2012; ISBN: 978-1-58763-416-1.

15. Faheem M. Inter-hospital transfer of critically ill patients (how the deficiencies in the system can be overcome). Dissertation, 2003.

16. Lietuvos Respublikos sveikatos sistemos ịstatymo Nr.I-552 2 ir 19 straipsnių pakeitimo ịstatymas Nr. XII-1387, TAR, 201412-12.

17. Lietuvos Respublikos sveikatos apsaugos ministro $2004 \mathrm{~m}$. spalio 15d., ịsakymas Nr.V-208 "Dèl būtinosios medicinos pagalbos ir būtinosios medicinos pagalbos paslaugų teikimo tvarkos bei masto patvirtinimo", VŽ, 2004; 160-5860.

18. Virketis G., Janušonis V., Kvekšaitė V. Skubi medicinos pagalba: tarphospitaliniai pervežimai. Tiltai, 2016; 1: 15-37. https://doi.org/10.15181/tbb.v73i1.1263

19. Virketis G, Janušonis V, Butrimas V. Admission to the emergency department of employment, the waiting time and queues investigation Lithuania Overview, 2017 (atiduota spausdinti).

20. Lietuvos Respublikos sveikatos apsaugos ministro $2004 \mathrm{~m}$. spalio 15 d., isakymas Nr. V-718 "Dèl greitosios medicinos pagalbos iškvietimų įvertinimo ir greitosios medicinos pagalbos brigados siuntimo ị iškvietimo vietą tvarkos aprašo patvirtinimo", TAR, 2015-08-31; 13193.

\section{NEW ATTITUDE OF EMERGENCY MEDICAL ASSISTANCE TRIAGE SYSTEM \\ G. Virketis, V. Matutytė}

Key words: emergency department, emergency medical assistance triage, vitally necessary medical aid.

Summary

Emergency department is the first place where patients are taken or come seeking for medical help. This department is vital to the proper attribution of a patient to certain medical emergency categories. As currently used 4 emergency medicals assistance categories do not meet the practical needs. The survey results of this study confirm that there is a need to widen triage scale from 4 to 5 in order to increase efficiency of the emergency department and to reach more targeted initial assessment of patients 'health state, which determines further testing and treatment.

The aim of the work is to observe and assess the opinion of the leaders and specialists of emergency medical care about the currently used four categories emergency medical assistance triage system imperfection and suggested 5 EMA categories.

Study object and methodology. Quantitative research was carried out by using a questionnaire survey method, data statistical analysis. The respondents were the heads of in-patient departments of the personal healthcare institutions and of ambulance services units, the heads/assistants of the reanimation, intensive care and emergency department units.

Results. 71 percent of respondents claim that critical health 


\section{6}

state cover only in 1 and 2 currently used EMA categories named clinical states. 68,1 percent of respondents agree that EMA categories should be widen up to 5 and the following titles were essentially covered all the states, from critical to ambulatory: critical, very urgent, urgent, non-urgent, and ambulatory. 82,9 percent of respondents agree that patient's EMA category must be registered in ambulance report.

Conclusion. The concept vitally necessary medical aid is not identical to medical assistance to preserve health and save life and corresponds merely to EMA categories 1 and 2. Currently used 4 category EMA triage system do not cover ambulatory emergency cases. Suggested 5 EMA categories and period of time within which the patients of the named EMA categories should start getting EMA: critical (immediately, within 10 min.), very urgent (from 10 to $30 \mathrm{~min}$.), urgent (from $30 \mathrm{~min}$. to 1 hour), non-urgent (from 1 hour to 2 hours $30 \mathrm{~min}$.) and ambulatory (from 2 hours 30 min. to 4 hours). To reduce patients' transportation to Emergency department should be used the same EMA triage system in ambulance and emergency department reports.

Correspondence to: virketis@kul.lt

Gauta 2017-11-06 